\title{
Social and Intellectual Rivalries and Their Narrative Representations in Biographical Dictionaries: The Representation of Ibn al-Ṣalāh-A Case Study
}

\author{
Mohammad Gharaibeh
}

Biographical dictionaries are important sources for the study of the social, cultural, and intellectual history of the premodern Islamicate world. And although documentary sources (including archeological artifacts, architecture, endowment deeds, numismatic evidence, manuscripts, and certificates of transmission $\left.\left[s a m \bar{a}^{c}\right]\right)$ have been used with increased regularity since the 1970s, the long-lasting mainstays for social and intellectual historians still remain biographical dictionaries in addition to other narrative sources. ${ }^{1}$ Especially the rich material of the Mamluk period provides the researcher with a wide variety of information about individuals, their social contacts, and their education. Biographical dictionaries also allow conclusions about larger trends regarding society or mobility, for example, if analyzed quantitatively. ${ }^{2}$

However, as tempting as the information provided by biographical dictionaries is for the study of social and intellectual history, it has certain limits due to the selection of material that the compiler needs to make from the sources he has at his disposal. These processes of selection, (re)arrangement, and altering of the materials result in a narrative framing of the past that is shaped by the worldview of the compiler and that is often described as authorial agency. While a growing number of studies analyze narrative strategies and authorial agency in chronicles, ${ }^{3}$ there are comparatively few studies that approach biographical dictionaries in the same manner. ${ }^{4}$ However, scholars such as Makdisi,

1 See Hirschler, Studying 16o-2.

2 See for example the studies of Petry, Civilian; Bulliet, Quantitative; Age; and Conversion; Mauder, Gelehrte; Romanov, Computational; as well as his website al-Raqmiyyāt. Digital Islamic history (https://alraqmiyyat.github.io/). They all use mostly biographical dictionaries quantitatively to reach broader conclusions about different aspects of Islamicate societies.

3 See for examples Hirschler, Medieval; Franz, Kompilation; or the contributions in Conermann (ed.), Innovation.

4 Exceptions are Malti-Douglas, Texts; and Keshk, How to frame; The historian's, who uses both 
Little, Cooperson, and Mujaddedi have already stated since the early 196os that the information in biographical dictionaries is influenced by the author's hidden agenda. Opwis has similarly highlighted that authors of biographical dictionaries of certain schools of thought (țabaqāt) are "not merely compilers of pre-existing information. Instead, they have an important impact on shaping the identity, the doctrine, and the authority structures of groups and individuals." ${ }^{5}$

The purpose of this paper is to add to the growing literature on biographical dictionaries as providers of (biased) knowledge, as opposed to archives of neutral information, ${ }^{6}$ by presenting a case study. Moreover, the paper wishes to draw attention to the possibility that the narrative framing of certain biographies may serve a very specific purpose in the life of the author besides being part of a larger frame of shaping the identity of groups. Hence, a significant part of this paper will deal with the context and the intellectual orientation of the authors as well as certain events that might have influenced the chosen narrative strategies. Central to this paper are the three Damascene Shāfiì scholars al-Dhahabì (d. 748/1348), with three of his biographical dictionaries, Ibn Kathīr (d. 774/1373), and Tāj al-Dīn al-Subkī (d. 771/1370), each with their țabaqāt works. The biographical entries for Ibn al-Ṣalāḥ al-Shahrazūrī (d. 643/1245) in each of these dictionaries are compared with each other.

Before going into further detail, though, a methodological remark needs to be made. In this paper, the biographical entries of one individual will be compared in all used dictionaries to outline the different narrative strategies and reconstruct the hidden agendas behind them. However, one could always oppose to this very narrow sample of examples, because from the perspective of quantitative methods, it is not representative enough to draw larger conclusions regarding the author's ideological, political, or intellectual agenda(s) that supposedly influence(s) the narrative strategies. This is, of course, a valid objection. And for the example of the Tärïkh al-islām of al-Dhahabī, which includes over 30,000 biographies, focusing on one single biography seems very insufficient.

The idea behind this approach, though, is that not all biographies included in a biographical dictionary are equally important to the author and his political and intellectual ideology. In addition, the content of the entries also varies

chronicles and biographical dictionaries; see also Gharaibeh, Narrative.

5 Opwis, Role 32.

6 While information can be defined as neutral data, knowledge is the information that has been selected according to its relevance and semantic content in regard to a certain idea or the agenda of the author. Lahn and Meister, Erzähltextanalyse 157. 
significantly from one to another. While some biographies only contain basic information, not sufficient enough to tell any story of the individual, others contain more detailed accounts forming knowledge that contains clear or subtle statements. From the perspective of a mere quantitative analysis, these variations in length and content might occur somehow arbitrarily. However, it is one of the main hypotheses underlying the present paper that a close analysis of the content against the backdrop of the intellectual and social setting of the author reveals the importance and significance of the biographical entry and, therefore, the knowledge included in it.

This also means that biographies can be significant for certain aspects of the author's intellectual and political ideologies or for situations, events, and rivalries in the life of the author. While some biographies and the knowledge contained in them may be crucial for the construction of a certain image of the author's school of law, or a more traditionalist or rationalist orientation of it, other biographies may have the function to justify specific actions and events or support a particular party within the struggle over resources. For a comprehensive understanding of the narrative strategies within a biographical entry, hence, a proper contextualization and an analysis of the author's social, intellectual, and political context is key.

It is for this reason that the biography of Ibn al-Ṣalāh is put at the center of the analysis and comparison, for it is considered here as crucial to all three authors that were examined. At least this is the hypothesis of the present paper, which will be proven throughout what follows, and the reason why it has been chosen among the other biographies. Certainly, there are more biographies that could have been chosen to support the argument of the paper. However, considering the significance of Ibn al-Ṣalāh, this case study demonstrates the close relation between knowledge included in biographical dictionaries and the political and intellectual agendas of the authors.

The article is structured as follows: section two describes the life and intellectual orientation of Ibn al-Ṣalāḥ. A special interest lies in the network of Ibn al-Ṣalāh and that of his students and the institutions where he and his students taught to demonstrate the impact of his teachings and his role in Shāfi'ite traditionalism. The next sections (three to five) deal with the lives and works of al-Dhahabī and Ibn Kathīr as representatives of the traditionalist movement and al-Subkī as representative of the rationalist movement. The analysis of their entries on Ibn al-Ṣalāh is put in the context of their intellectual orientations and social networks. The article ends with a conclusion (section six), in which the findings of the article are summarized and discussed. 

Traditionalism in Damascus

Recent scholarship has highlighted the struggle between Shāfi'i traditionalists and Shāfiì rationalists in Damascus during the 8 th/14th century. ${ }^{7}$ Those studies usually put the network of the traditionalist Shāfi îs in the context of the Hanbalī reform thinker Ibn Taymiyya and focus on individuals such as Ibn Kathīr, al-Dhahabī, al-Birzālī, and al-Mizzī. While there is no denial of the importance of the influence of Ibn Taymiyya - and probably the circle of his (Hanbalī) adherents, such as Ibn Qayyim al-Jawziyya ${ }^{8}$ — one cannot but observe a tendency for Shāfici scholars to call for stronger integration of the scripture (Quran and hadìth) into legal reasoning, as opposed to the $u s \underline{u} l$ al-figh being based on rational science (such as logic), during the 7 th century. One of the more prominent representatives of this early traditionalism is Abū Shāma al-Maqdisī. The increasing interest to integrate hadith, in particular, within legal debates is documented in Mukhtașar al-Mu'ammal, in which Abū Shāma rejects ra'y-based jurisprudence, blaming the fuqah $\bar{a}^{3}$ for taking the ahādith, if ever, from books without isnād and not evaluating the authenticity of them. He cites a number of Shāfiì scholars, among them al-Shīrāzī (d. 476/1083), al-Māwardī (d. 450/1058), and Ibn al-Ṣabbāgh (d. 477/1084), and some examples where the authors used unreliable material or even contradict prophetic statements. ${ }^{9}$

A no less popular scholar, but usually less known for his traditionalist tendencies and whose role within the traditionalist movement of Damascus is undoubtedly underestimated, is Ibn al-Ṣalāh. The present paper argues that an analysis of Ibn al-Ṣalāḥ's role in the Damascene scholarly scene, his own writings, especially his Muqaddima, and the network of his students, supports our understanding of the history of traditionalism in Damascus. The noticeable conflict between traditionalists and rationalists in the 8th/14th century was only the tip of the iceberg of a broader development that had already taken place in Damascus in the 7 th/13th century. Moreover, the different narrative framings of Ibn al-Ṣaläh's biography by authors of the 8th/14th century can, therefore, be seen as a result of the rivalry between those two camps. Also, they are strategies to dominate in the struggle about (intellectual) dominance, resources, and (teaching) institutions in Damascus. Taking a look at Ibn alȘalāḥ’s life, work, and students is necessary to explain all of this.

7 See, in particular, the studies of Younus Mirza on Ibn Kathīr and of Nahyan Fancy on Ibn al-Nafîs (see bibliography).

8 See, for Ibn Taymiyya's closer circle of students, Bori, Ibn Taymiyya.

9 Abū Shāma did in his Mukhtașar 42-53. 
Taqī al-Dīn Abū 'Amr 'Uthmān b. al-Muftī Ṣalāḥ al-Dīn 'Abd al-Raḥmān b. 'Uthmān b. Mūsā l-Kurdī l-Shahrazūrī l-Shāfi'ì, commonly known as Ibn alȘalāh, was born in 577/1181 in Sharakhān, a village in the Shahrazūr region in Kurdish northern Iraq. ${ }^{10}$ As a son of a local scholar and mufti, he received his early education from his father in Irbil, the capital of one of the minor principalities between the Khwārazmians in the East and Ayyubids in the West.11

After his basic education, Ibn al-Șalāh left Irbil for Mosul, where he continued his studies. He deepened his legal training there with at least three scholars. First to mention is 'Ubayd Allāh b. Saminn (d. 588/1192), with whom Ibn al-Ṣalāḥ read the legal manual of Abū Isḥāq al-Shīrāzī, al-Muhadhdhab fì lfurū'.$^{12}$ The second scholar was 'Imād al-Dīn Abū Ḥāmid Muhammad b. Yūnus b. Min'a al-Irbalī al-Mūṣilī (d. 6o8/1211), with whom he entertained close relations ${ }^{13}$ and with whom Ibn al-Ṣalāḥ studied the law-related works of al-Ghazālī (i.e., the Wasit fi l-madhhab and the Wajiz fi figh al-Shäfic $).{ }^{14}$ The third and probably most influential Shāfíi scholar Ibn al-Ṣalāḥ studied with in Mosul was al-Kamāl Mūsā b. Yūnus (551-637/1156-1240), the brother of al-'Imād. AlKamāl was known for his wide knowledge and expertise in many fields of the Islamic disciplines, including the so-called rational disciplines. ${ }^{15}$ According to Ibn Khallikān, Ibn al-Ṣalāḥ even wanted to study logic with al-Kamāl b. Yūnus but gave up after some fruitless attempts. Al-Kamāl recommended Ibn al-Ṣalāh not to invest any more time in studying this discipline because of his lack of talent and the bad reputation logic had among religious scholars, who would eventually harm the reputation of Ibn al-Ṣalāh. ${ }^{16}$

By the time Ibn al-Ṣalāḥ ended his study in Mosul, he had acquired extensive legal knowledge and expertise in the two țariqas (communities of interpreta-

10 The most elaborated biography of Ibn al-Ṣalāh in the secondary literature is still the one provided by Dickinson in the introduction of his translation of Ibn al-Ṣalāḥ's Muqaddima. The biographical notes provided here follow mostly his outlines in Ibn al-Ṣalāḥ, Márifat xiv-xxiii.

11 See Ibn al-Ṣalāh, Márifat xv.

12 See Ibn al-Ṣalāḥ, Márifat xvi.

13 Which can be seen by the fact that Ibn al-Ṣalāh became the mu'ìd of al-Imād b. 'Yūnus. See al-Dhahabī, Tadhkirat iv, 1430.

14 Ibn Khallikān, Wafayāt iv, 253.

15 This includes, e.g., knowledge in fann al-hikma, logic (al-manțiq), al-țabīt, al-ilāhī, also medicine, iqlīdas, al-hay'a, al-makhrūțāt, and al-majisțī; math with all its subdisciplines (such as al-jabr, al-muqābala, al-arithmāțīqū), țarīq al-khața’ayn; music, grammar-he had read Kitāb Sïbawayh and al-Ị̇āh and of Abū 'Alī l-Fārisī, al-Faṣl of al-Zamakhsharīhistory, ayyām al-'arab wa-l-waqā' $i$ ', and poetry. See, for this and for a lengthy biography of al-Kamāl in general, Ibn Khallikān, Wafayāt v, 311-7.

Ibn Khallikān, Wafayāt v, 314. 
tion) of the Shāfici school of law, which was represented by the legal manual of Abū Isḥāq al-Shīrāzī, al-Muhadhdhab fì l-furū' as part of the Iraqi țarìqa, on the one hand, and the works of al-Ghazālī, who was the representative of the Khurasanian tarīqa of the Shäfi' ì school of law, on the other. ${ }^{17}$ Together with the anecdote of his lack of success in the field of logic, these snippets of information were crucial for his later career in the Ayyubid territory, especially in Damascus.

From Mosul, Ibn al-Ṣalāḥ performed a longer journey that seemed to be ded-

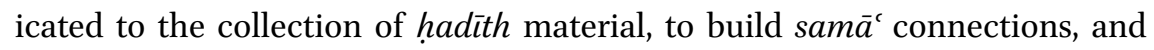
to achieve some valuable isnāds. His travel took him to cities such as Bagdad, Dunaysar, Hamadhān, Nishapur, Marw, Damascus, Aleppo, and Hawran. ${ }^{18}$ The interest of Ibn al-Ṣalāḥ in hadìth studies must be seen as rather exceptional, in his time, for scholars of jurisprudence ( fuqahā). As the works of al-Shīrāzī and al-Ghazāli indicate, jurists of this period and region did not seem to have extensive training in the evaluation of the authenticity of hadith. Since they built their legal reasoning on the rulings of previous jurists, which were based on a well-defined corpus of prophetic traditions (and Quranic verses), there was no need for them to search for additional traditions or to evaluate other material. Ibn al-Ṣalāh, with his rather unusual engagement in the study and transmission of hadith and his broad legal training, was probably among the first Shāfi'i scholars who combined the study of law and hadìth.

It is somehow an enigma how, and also when, exactly Ibn al-Ṣalāḥ settled in Ayyubid territory. At some point, Ibn al-Ṣalāh took over the teaching position in the Asadiyya school in Aleppo, then in the Șalāhiyya school in Jerusalem around 615/1218, before he entered Damascus around 619/1222. ${ }^{19}$ In Damascus, Ibn al-Ṣalāh could not easily take root in the scholarly landscape during the reign of al-Malik al-Mu'azzam 'Īsā (r. 615-24/1218-27). This was due to the latter's promotion of the ancient sciences (philosophy and logic) and his suppression of traditionalism, in particular the rising influence of the Hanbali community that had settled in the Șālihiyya region in $551 / 1156 .{ }^{20}$ Eventually, Ibn al-Ṣală managed to achieve the teaching position and the supervision (tadrīs wa-nazar) of the Rawāhiyya school in Damascus in 622/1225. ${ }^{21}$ But his career in

\footnotetext{
17 See, for a description of the two Communities of Interpretation of the Shāfi'i school of law, Halim, Legal $53-79$.

18 See, for a more detailed list of individuals Ibn al-Ṣalāh heard from during his years of traveling, al-Dhahabī, Tadhkirat iv, 1430; Tärīkh xiv, 455; and Siyar, 2659.

19 Ibn al-Ṣalāh, Márififat xvi-xvii.

20 See, for the history of migration of the Hanbalī al-Maqdisī family, Leder, Charismatic esp. 283-4.

21 Al-Nu'aymī, Dāris i, 199-20o.
} 
Damascus took a peak after al-Ashraf Mūsā (r. in Damascus 626-35/1229-37) gained control over Damascus in 626/1229. ${ }^{22}$ Unlike his brother al-Mu'azzam 'Īsā, al-Ashraf Mūsā had no business with the rational sciences and aimed for their banishment from Damascus. ${ }^{23}$ Ibn al-Ṣalāh provided him with the legal justification for this with two fatwās, which he issued on the questions: "Is it permissible to read the works of Ibn Sinnā?" and "Is it permissible to engage in logic and philosophy?"24 Ibn Kathīr even called Ibn al-Șalāh the Imam of the Sultan, which indicated the close relationship he must have maintained with him. ${ }^{25}$ In addition, Ibn al-Ṣalā of his pilgrimage to Mecca, to the teaching position of the Shāmiyya school. ${ }^{26}$ Eventually, Ibn al-Ṣalāh was given the mashyakha, the teaching position, in the Dār al-Hadith al-Ashrafiyya that opened in 630/1233. Al-Ashraf Mūsā erected a similar Dār in the Șâlihiyya region exclusively for Ḥanbalī scholars, the Dār al-Ḥadīth al-Ashrafiyya al-Barrāniyya, ${ }^{27}$ which shows his support of traditionalism in general and Ḥanbalism in particular. Ibn al-Ṣalāh also held this position for about 13 years, until his death in 643/1245, and it became the institution he was associated with the most. During his teaching there, Ibn al-Ṣalāh compiled his famous treatise on the hadïth science, known as Muqaddimat Ibn al-Saläh, together with some other writings. He died in Damascus in 643/1245 and was buried at the Șüfiyya cemetery.

In contrast to his early academic career, in which Ibn al-Ṣalāḥ had shown some interest in the rational sciences, his later career, especially in Damascus, was almost exclusively dominated by a traditionalist orientation. This is also expressed in his writings, ${ }^{28}$ which show a clear focus on the two main subjects of his interest, i.e., the fields of jurisprudence ( figh and ușül figh) and hadīth.

Especially his jurisprudence-related works demonstrate his broad legal education in the two Shāfi'i tarīqas on the one hand but also his interest in the

22 See Humphreys, Saladin $193^{-208 .}$

23 See Ibid. 208-14.

24 See Ibn al-Ṣalāh, Fatāwā i, 208-12. See also for a description of al-Ashraf's religious policy, his tendency to promote traditionalism, and the resulting struggle over curricula among the scholarly elite, especially between Sayf al-Dīn al-Āmidī and Ibn al-Ṣalāḥ, the unpublished MA thesis of al-Azem, Traditionalism.

25 Ibn Kathīr, Bidāya xvii, 112.

26 See al-Nu'aymī, Dāris i, 208-9.

27 This school is also known in the sources as the Shāmiyya al-Barrāniyya and the Shāmiyya al-Ḥusāmiyya as well as the Ḥusāmiyya school. See al-Nu'aymī, Dāris i, 36-42.

28 The editors of his works have invested good efforts to collect the titles of his writings from the various sources. The given list here is based on the overview provided by the editor of Ibn al-Ṣalāḥ, Adab, 17-9. 
hadìth sciences and his desire to include hadīth in legal reasoning. His works, e.g., Sharh mushkil al-Wasiț (the original al-Wasiț was written by al-Ghazālī [d. 505/1111]), provide a reference to the sources of each hadith used in the original and evaluate the authenticity of each hadith. ${ }^{29}$

Ibn al-Ṣalāh also compiled a biographical dictionary, i.e., his Ṭabaqāt alShäficiyya, which is probably the first Tabaqāt work dedicated to the Shāfi $\overline{1}$ school written in Damascus. It is interesting to note that the Damascene authors of the other Tabaqāt al-Shāficiyya works have all taught in the Dār alHadīth al-Ashrafiyya, like Ibn al-Ṣalāh, who seems to have compiled his work there. This includes the works of al-Nawawī, Ibn Kathīr, and Tàj al-Dīn alSubkī. ${ }^{30}$

His Muqaddima and his commentary on the "introduction" of Muslim's Șahịh work ${ }^{31}$ deal primarily with the categorization of many hadìth and isnād variations. Although it is tempting to perceive these works as entirely dedicated to the discipline of hadith studies, one needs to keep in mind that Ibn al-Ṣalāh called for a stronger integration of hadith into legal reasoning. His Muqaddima might have been an attempted implementation of this endeavor. For a stronger integration of hadīth in legal reasoning, the authenticity of narrations was given crucial importance to distinguish valid from invalid hadith to justify legal rulings. Providing future Shāfiī jurists with a manual to help them categorize narrations and to determine their authenticity, especially the Muqaddima was probably a crucial (teaching) tool.

\section{Ibn al-Ṣalăḥ and His Importance for the Shäfīi Scholarly Elite in Damascus and the Division of the Shäfī Community into Traditionalists and Rationalists}

From what has been stated above, Ibn al-Ṣalāh can be described as one of the first Shāfi'i (migrated) scholars of Damascus who called for a stronger integration of hadith in legal reasoning and a refutation of the rational sciences, particularly logic and philosophy. This becomes particularly obvious considering the fact that during the 6 th $/ 12$ th and early 7 th $/ 13$ th centuries, Damascus was dominated by local Damascene Shāfici scholarly families who were adherents of the Ash'arī school. ${ }^{32}$ The influx of Shāfíi scholars from the East, especially

\footnotetext{
29 See Ibn al-Ṣalāḥ, Sharh 62-3.

30 See, for an overview of the teachers of the Dār al-Ḥadìth al-Ashrafiyya, al-Nu'aymī, Dāris i, $15-36$.

31 This work is entitled Șiyānat Șaḥ̂h Muslim min al-ikhläl wa-l-ghalaț wa-himāyatuhu min al-isqāt wa-s-saqaț. See Ibn al-Ṣalāḥ, Șiyānat.

32 This includes the al-Khushū'î family, the Ibn 'Asākir family, the Ḥubūbī family, the Ibn alZakī family, as well as the Ibn Șașrā family. See for this the comprehensive study of Ibn
} 
from Iraq, seemed to have challenged the standing of the local families, particularly since they found new patrons under late Ayyubid rule and replaced the locals in many teaching institutions. Since Ibn al-Ṣalāh was one of those early Shāifìs who had a significant impact on later generations through his appointment at the Dār al-Ashrafiyya school, it can be assumed that authors of biographical dictionaries would have had a special interest in him. Moreover, the image an author of a biographical dictionary would draw of Ibn al-Ṣalāh would certainly depend on his own intellectual orientation, i.e., whether or not he shared the latter's hadith-oriented theological and legal approach.

To better understand the stance of the biographers al-Dhahabī, Ibn Kathīr, and al-Subkī toward Ibn al-Ṣalāh, it is helpful to analyze how they relate to Ibn al-Ṣalāh socially and intellectually and to compare the findings with the content of their dictionaries. Since all authors were born after Ibn al-Ṣalāḥ's death and none of them could have met him personally, it is necessary to take a closer look into Ibn al-Ṣalāḥ's impact on the Shāfici scholarly community. An entire analysis of this, however, is nearly impossible and would go beyond the scope of this paper. Instead, Ibn al-Șalāḥ's impact will be measured by an analysis of the social network of his closer students, their control over teaching institutions, and the reception of Ibn al-Ṣalāḥ's writings. If we take his most significant work, the Muqaddima, as an example to trace back its reception, it turns out that the social network of students, the control over teaching institutions, and the reception are closely related to each other. ${ }^{33}$

2.1.1 The Network of Ibn al-Ṣalāḥ's Students

Among the closest students of Ibn al-Ṣalāḥ are the Shāfi ī scholars Shams al-Dīn 'Abd al-Raḥmān b. Nūḥ al-Turkmānī l-Maqdisī (d. 654/1256), ${ }^{34}$ Kamāl al-Dīn Salār (d. 670/1272), ${ }^{35}$ Kamāl al-Dīn Isḥāq (d. 65o/1252), ${ }^{36}$ Taqī al-Dīn Ibn Razīn

'Azzūz, Buyūtāt. See, for the relation of the Ibn 'Asākir family with the Ayyūbid sultan Ṣalāh al-Dīn and the foundation of the Dār al-Ḥadīth al-Nūriyya, Mourad and Lindsay, Intensification.

33 See, for the larger argument of the replacement of local Damascene families by migrated Shāfi'is, the change in the appointment strategies, the spread of Ibn al-Ṣalāḥ's students, as well as the close relation between the reception of his Muqaddima and the emerge of traditionalism in Damascus, Gharaibeh, Sociology. Most of the findings presented here were drawn from this Habilitation Thesis.

34 See, for his biography, al-Subkī, Tabaqāat viii, 188; al-Dhahabī, Tārīkh xiv, 758; Ibn Kathīr, Bidāya xvii, 346 .

35 See, for his biography, al-Subkī, Ṭabaqāt viii, 149; al-Dhahabī, Siyar 186o-1; Ibn Kathīr, Tabaqāt ii, 807-8.

$3^{6}$ See, for his biography, al-Dhahabī, Tārīkh xiv, 635; Ibn Kathīr, Țabaqāt ii, 777; see also Abū Shāma, Tarājim 187, who referred to him as al-Muqri'. 
(d. 68o/1281), ${ }^{37}$ who later was the judge of Egypt ( qādī l-diyāa al-mișriyya), Shihāb al-Dīn 'Abd al-Raḥmān b. Ismāîi Abū Shāma al-Maqdisī (d. 665/1267), and Shams al-Dīn Ibn Khallikān (d. 681/1282), who was appointed as judge over Syria (qā dì l-shām), as well as al-Fakhr 'Umar b. Yahyeā l-Karjī (d. 69o/1291), ${ }^{38}$ al-Majd Yūsuf b. al-Mihtār (d. 686/1287) (39 $^{39}$ d his son Muhammad b. Yūsuf b. alMihtār (d. 715/1315) ${ }^{40}$ and al-Jamāl Abū Bakr Muhammad b. Aḥmad al-Sharīshī (d. $685 / 1286){ }^{41}$

These individuals played a major role in the transmission of the Muqaddima. Ibn Razin, for example, is the social link to the transmission of the text to Cairo, where individuals such as al-Badr b. Jamāa (d. 733/1333), ${ }^{42}$ one of the later commentators on the Muqaddima, studied it with him. Also, scholars such as Ibn Ḥajar al-'Asqalānī (d. 852/1448) narrated the Muqaddima through an isnād that led through Ibn Razīn to Ibn al-Ṣalāh. ${ }^{43}$ Al-Faḥr al-Karjī (d. 69o/1291) and al-Majd al-Mihtār (d. 686/1287), together with his son Muhammad al-Mihtār (d. 715/1315), witnessed the teaching of the Muqaddima, either as a scribe of the țibāq (al-Fakhr al-Mihtār) during the reading session, as a reader (al-Karjī), or as a listener (Muhammad al-Mihtār). Moreover, they also took over the teaching positions in several schools and Dür al-Hadìth, so it can be assumed that the Muqaddima was taught there as well. Among the most important ones for the scope of the present paper are the Dār al-Ḥadìth al-Ashrafiyya, the Dār alHadìth al-Nūriyya, and the Rawāhiyya school. The list of individuals reveals that most of them had social ties to either Ibn al-Ṣalāh directly or to his students and that they had studied the Muqaddima of Ibn al-Ṣalāḥ and, assumingly, had

37 See, for his biography, al-Subkī, Țabaqāt viii, 46-8.

38 See, for his biography, Ibn Kathīr, Bidāya xvii, 644; al-Dhahabī, Tārīkh xv, 669-70.

39 See, for his biography, al-Dhahabī, Tärīkh xv, $5^{6} 3$.

40 See, for his biography, Ibn Ḥajar, Durar iv, 313 .

41 He is al-Jamāl Abū Bakr Muḥammad b. Aḥmad b. Muḥammad b. 'Abdallāh b. Sujmān alBakrī al-Wāiilī al-Andalusī al-Sharīshī al-Mālikī, who was born in 6o1/1205 in Sharīsh. He heard in Alexandria, Bagdad, Irbal, and Damascus. For some time, he taught in Cairo in the Ribāṭ al-Nāṣirī and at the Fāḍiliyya school. After that he went to Damascus where he assumed the teaching post in the Dār al-Hadīth al-Nūriyya, the reading circle in the Umayyad Mosque, the mashyakha of the Ribāṭ and the teaching in the Umm al-Ṣālih. He heard from Ibn al-Ṣalāh the Muqaddima. Among his students or those who narrated from him were Ibn Taymiyya, al-Mizzī, Ibn al-Aț̣āâ, al-Birzālī al-Ṣayrafì, Ibn al-Khabbāz, and others. Al-Dhahabī received an ijāza for his marwiyyāt, among them the Muqaddima, in 674/1275. See for his biography al-Dhahabī, Tārīkh xv, 549-52.

The most helpful and complete list of students of Ibn al-Ṣalāh is given by al-Dhahabī in his Tärīkh, where he differentiated between those who studied law with Ibn al-Ṣalāḥ and those who took hadìth from him. See al-Dhahabī, Tärīkh xiv, 457.

42 See for this Ibn al-'Imād, Shadharāt viii, 185; and Ibn Jamā'a, Mashyakha ii, 489 .

43 See for this Ibn Hajar, Mujma ii, $75^{-6}$; 289 . 
also taught it during their appointment at the Dār or the school. Interestingly, in all institutions, a shift from traditionalist to rationalist scholars that coincided with the peak of the conflict between the traditionalist and rationalist Shāfiì scholars was noticeable during the 8th /14th century.

\subsubsection{The Dār al-Hadith al-Ashrafiyya}

Among the individuals who taught in the Dār al-Hadìth al-Ashrafiyya were al-Nawawī (d. 676/1277), ${ }^{44}$ Zayn al-Dīn 'Abdallāh b. Marwān al-Fāriqī (d. 703/ 1303), ${ }^{45}$ Muḥammad b. 'Umar b. al-Wakīl (d. 716/1316), ${ }^{46}$ Muhammad b. 'Alī alZamlakānī (d. 727/1327), ${ }^{47}$ Ahmad b. Muḥammad al-Sharīshì (d. 718/1318), and Abū l-HajjājJamāl al-Dīn Yūsuf al-Mizzī (d. 742/1341) ${ }^{48}$ All of them had studied the Muqaddima, either with Ibn al-Ṣalāh directly or with one of his students, and can be characterized as having a notion toward traditionalism. After the death of al-Mizzī in 742/1341, however, al-Taqī al-Subkī (d. 756/1355) was appointed in the Dār al-Ḥadīth al-Ashrafiyya. Taqī al-Dīn 'Alī b. 'Abd al-Kāfĩ al-Subkī was sent by the Sultan al-Nāșir Muhammad b. Qalāwūn from Cairo, specifically to exercise the post of Shafi i chief judge in Damascus. ${ }^{49}$ With him, a clear shift can be seen from the more traditionalist orientation of a teacher with the pos-

44 See, for his biography, for example, al-Dhahabī, Tadhkirat al-huffāz, iv, 1470-4; al-Subkī, Țabaqāt, viii, 395-400; and more extensively the three biographies on al-Nawawī by Ibn al'Aț̣ār, Tuhfat al-țālibīn; al-Sakhāwī, al-Manhal al-'adhib; and al-Suyūṭī, al-Minhāj al-sawī. Al-Nawawī studied with Shams al-Dīn 'Abd al-Raḥmān al-Maqdisī, Kamāl al-Dīn Isḥāq, and al-Imām Kamāl al-Dīn Salār. Moreover, al-Nawawī lived in the Rawāḥiyya school during his entire stay in Damascus and authored three commentaries on the Muqaddima of Ibn al-Ṣalāḥ.

45 See, for his biography, Ibn Ḥajar, Durar ii, 304-5. He heard from Ibn al-Ṣalāh directly.

46 See, for his biography, al-Subkī, Tabaqāt ix, 253-67. His orientation is not quite clear. Although al-Subkī described Ibn al-Wakī as being close to Ibn Taymiyya and like him ( $m \bar{a}$ huwa baìd 'anhu), he also stated that his father, al-Taqī al-Subkī, said that Ibn al-Wakīl had a good creed and knew kalām in the way of the Ash'arī school (husn al-'aqìda wa-ma'rifat al-kalām 'alä madhhab al-ash'arī). See ibid., 254. Of course, there is always the possibility that the description of al-Subkī also serves his hidden agenda.

47 See, for al-Zamlakān̄’s biography, Ibn Kathīr, Bidāya xviii, 286-8; and Ibn Ḥajar, Durar iv, 74-6. He studied with some of Ibn al-Ṣalāḥ's students, such as al-Tāj 'Abd al-Raḥmān alFazārī.

48 See, for a comprehensive biography of al-Mizzī, Mirza, Ibn Kathìr, 32-6. He studied with and heard from al-Tāj al-Fazārī, al-Shihāb al-Khuwayy, al-Majd b. al-Mihtār (d. 686/1287), al-Jamāl al-Sharīshī (d. 685/1286), and from al-Fakhr al-Ba labakkī l-Ḥanbalī (d. 688). See, for an overview of teachers in the Dār al-Ḥadīth al-Ashrafiyya, al-Ḥāfiẓ, Dūr al-Hadīth 596 o.

49 See, for his biography, Ibn Ḥajar, Durar iii, 63-71; see, for al-Subki’s career in Damascus, Leder, Damaskus, 244-9. 
sibility of having taught the Muqaddima in the Dār toward a more rationalist orientation.

After al-Taqī, his son, al-Tāj 'Abd al-Wahhāb b. 'Alī (d. 771/1370), took over the teaching position of the Ashrafiyya. ${ }^{50}$ After his death and for a short period of about three years only, Ibn Kathīr (d. 774/1373) seemed to be the next teacher of the Dār. The individuals who followed him had only little contact with transmitters of the Muqaddima in particular or traditionalists in general. They are 'Umar b. 'Uthmān b. Hibat Allāh al-Ma'arrī l-Ḥalabī (d. 783/1381), ${ }^{51}$ al-Bahā' Muḥammad b. 'Abd al-Barr al-Subkī (d. 777/1375), ${ }^{52}$ Abū Dharr 'Abdallāh b. Muhammad b. 'Abd al-Barr al-Subkī (son of the former) (d. 785/1383), ${ }^{53}$ alBurhān Ibrāhīm b. 'Abd al-Rahīm Ibn Jamāca (d. 79o/1388),54 Muhammad b. Muḥammad b. 'Abd al-Rahīim al-Sulamī l-Macarrī (d. 799/1397),55 and Aḥmad b. 'Umar b. Muslim b. Sacìd al-Milhị al-Dimashqī (d. 793/1391).56

\subsubsection{The Dār al-Hadìth al-Nūriyya}

Among the individuals who taught in the Dār al-Ḥadīth al-Nūriyya were alTāj al-Fazārī (d. 69o/1291) (student of Ibn al-Ṣalāḥ), Yūsuf b. al-Ḥasan b. Badr al-Nābulsī l-Dimashqī (d. 671/1272), al-Jamāl Abū Ḥāmid Muḥammad b. 'Alī b. Maḥmūd b. al-Ṣābūnī (d. 68o/1281), al-Majd b. al-Mihtār (d. 686/1287) (scribe of the Ashrafiyya, transmitter of the Muqaddima, and student of Ibn al-Ṣalāḥ), al-Fakhr al-Ba'labakkī (d. 688/1286) (student of Ibn a-Ṣalāḥ), al-Sharaf Ahmmad b. Aḥmad b. Ni'ma al-Maqdisī l-Shāfíi (d. 694/1295), al-'Alā' 'Alī b. Ibrāhīm b. Dāwūd al-'Ațtāar (d. 724/1324) (student of al-Nawawī), al-'Alam al-Qāsim b. Muḥammad b. Yūsuf al-Birzālī (d. 739/1338) (heard from al-Fazārī and Ibn alMihtār), Jamāl ad-Dīn Abū l-Hajjāj Yūsuf al-Mizzī (d. 742/1341) (heard from al-Fazārī and Ibn al-Mihtār), and 'Abd al-Raḥmān b. Yūsuf al-Mizzī, son of Abū

50 Al-Ḥāfiz, Dūr al-Hadīth 6o. And for his biography, Ibn Ḥajar, Durar ii, 245-8.

51 See, for his biography, Ibn Hajar, Durar iii, 177, who did not mention any educational ties that indicate he had read the Muqaddima.

52 See, for his biography, Ibn Hajar, Durar iii, 490-1, who mentioned relations to al-Mizzī and al-Birzālī. But given him belonging to the Subki family, he probably was a rationalist, too, and rather opposed traditionalism, so that his ties to al-Mizzī and al-Birzālī could have been of a technical nature.

53 See, for his biography, Ibn Ḥajar, Durar ii, 29o. Abū Dharr also heard from al-Mizzī.

54 See, for his biography, Ibn Ḥajar, Durar i, 38-9. Among his samāc relations, al-Mizzī and al-Dhahabì are listed.

55 Could not be identified.

56 See, for his biography, Ibn Ḥajar, Durar i, 232. No indications of any contact with transmitters of the Muqaddima are given. For the overview of the teachers in the Ashrafiyya, see al-Ḥāfiż, Dūr al-Hadìth 6o. 
l-Hajjāj (749/1348). ${ }^{57}$ Those individuals can almost exclusively be counted as Shāfici traditionalists (with the exception of al-Fakhr al-Ba'labakkī, who was a Ḥanbalī scholar) and had either direct contact with Ibn al-Ṣalāḥ or with one of his students.

For the individuals after 'Abd al-Rahmān al-Mizzī, quite the opposite seems to be the case. They can either be identified as Shāfiì rationalists and/or as having had little or no contact with Ibn al-Ṣalāḥ or his students. They were Muḥammad b. Muḥammad b. al-Khațịb Ibn Nubāta, ${ }^{58}$ Muḥammad b. Rāfi b. Hajras al-Shallāmī (d. 774/1372), ${ }^{59}$ and Muḥammad b. Mūsā b. Muḥammad alLakhmī l-Dimashqī (aka Ibn Sanad) (d. 792/139o). ${ }^{60}$ All three scholars migrated from Cairo to Damascus and were close associates of al-Tāj al-Subkī and, therefore, represent a rather rationalist orientation.

\subsubsection{The Rawāhiyya School}

The Rawāhiyya school, together with the Dār al-Hadìth al-Ashrafiyya, was one of the two institutions in which Ibn al-Ṣalāh could spread his knowledge the most. After a long period in which his students were teaching there, interestingly, a change of intellectual orientation can be identified with the appointment of Abū l-Thanā' Mạ̣mūd b. 'Abd al-Raḥmān b. Aḥmad b. Muḥammad b. Abū Bakr b. 'Alī b. al-Ișfahānī (d. 749/1348), at the latest. ${ }^{61}$ After al-Iṣfahānī, 'Abdallāh b. al-Majd or al-Shihāb Aḥmad b. al-Majd 'Abdallāh was appointed for only one year in 733/1333. ${ }^{62} \mathrm{He}$ was replaced by al-Fakhr Abū l-Faḍāil Muhạammad al-Mișrī (d. 751/1350) in 734/1334. ${ }^{63}$ After him, three members of

57 Al-Ḥāfiz, Dūr al-Hadìth 13-4.

$5^{8}$ See, for his biography, al-Ṣafadī, Wãf $\iota$ i, 208-9; Ibn Ḥajar, Durar iv, 173-4. He is the father of a famous poet, migrated from Egypt to Damascus, and had no contact with the transmitters of the Muqaddima. He also did not have any (educational) contact with the traditionalist Shāfičis of Damascus.

59 See, for his biography, Ibn Ḥajar, Durar iii, 439-40.

6o See, for his biography, Ibn Ḥajar, Durar iv, 270-1. See al-Ḥāfiz, Dūr al-Hadīṭ 18-9.

61 Before Ibn al-Iṣfahānī, Kamāl al-Dīn Muhammad b. 'Alī l-Zamlakānī (d. 774/1327) was appointed in the Rawāhiyya, who had also taught in the Dār al-Hadīth al-Ashrafiyya. See, for this, al-Nu'aymī, Dāris i, 204. Al-Ișfahānī was born in Ișfahān in 694/1295 and educated in Tabriz. He came to Damascus in 725/1325. He spent about eight years in Damascus and then moved to Cairo in 733/1333, where he died in 749/1348. In Damascus, he compiled a famous Quran exegesis but was also very famous for his treatises on logic, kalām, and philosophy. See, for his appointment at the Rawāhiiyya school, al-Nu'aymī, Dāris i, 204-5; and for his biography al Ghouz, Brokers.

62 Al-Nu'aymī, Dāris i, 205. Unfortunately, he could not be identified.

63 His biography in Ibn Ḥajar, Durar iv, 51-3. Ibn Ḥajar does not mention any hadìth related information in al-Fakhr al-Mișrì's biography, so it is very unlikely he would have studied 
the al-Subkī family were appointed in the Rawāhiyya, indicating a clear change in the intellectual orientation of this school from traditionalism to the rationalist orientation. They were al-Bahā' Abū l-Baqā' al-Subkī, who also taught in the Ashrafiyya, his son Qāọī l-Quḍāt al-Walī Abū Dharr 'Abdallāh al-Subkī, also a teacher in the Ashrafiyya, and after him, al-Badr Abū 'Abdallāh Muhammad b. al-Bahā' al-Subkī. ${ }^{64}$

The overview of the teachers in those three institutions indicates two important things. First, for a period of about 70 years, teachers dominated those institutions that had close links to Ibn al-Ṣalāh or his students, who had studied the Muqaddima and probably also taught it and who can be described as having a general tendency toward traditionalism. Second, at some point at the beginning of the 8th/14th century (around the 20 s or 3os) individuals who had tendencies toward rationalism or could clearly be identified as rationalist Shāfi'is were appointed. The domination of traditionalist scholars over these institutions seemed to have come to an end. The al-Subki family, as well as other migrated scholars (mostly from Cairo), played a significant role in this change. All the authors of the biographical dictionaries that are the center of this study lived in this crucial period, and it can be assumed that they authored their dictionaries under the influence of these ongoing changes. For Ibn Kathīr and al-Subkī, one can even assume that they authored their dictionaries during their teaching time at the Dār al-Hadìth al-Ashrafiyya. Therefore, it is of particular interest to see how the authors of the biographical dictionaries relate to these individuals and whether or not they can be characterized as traditionalists or rationalists to see what kind of purpose might have stood behind their narrative framing of Ibn al-Ṣalāḥ's biography.

Al-Dhahabī and Ibn Kathīr: The Traditionalists View

\section{1}

\section{Al-Dhahabì}

Shams al-Dīn Muḥammad b. Aḥmad b. 'Uthmān b. Qaymāz b. 'Abdallāh alTurkmānī al-Fāriqī al-Dimashqī al-Shāfi'ī al-Dhahabī was born in Damascus in the village Kafarbațnā, as a descendant of a Turkish family, in $673 / 1275{ }^{65}$ In the same year, he was already granted child $i j \bar{a} z \bar{a} t$ by the brokerage of another

or even taught the Muqaddima in the Rawāhiyya. See, for his appointment, al-Nu'aymī, Dāris i, 184-8.

64 Al-Nu'aymī, Dāris i, 205.

65 See al-Shaykh, al-Häfiz 27. 
scholar. His foster brother (akhūh min al-raḍ̄a'a), the Shāfi'ite scholar 'Alä' alDīn Abūl-Ḥasan 'Alī b. Ibrāhīm b. Dāwūd b. al-Aț̣āar (d. 724/1324) mediated that ijāzāt for him. ${ }^{66}$ Himself a well-known scholar, Ibn al-Ațtār was also known as Mukhtașar al-Nawawì, a nickname he earned because of his constant company (mulāzama) with Muhȳī l-Dīn al-Nawawī (d. 676/1277). ${ }^{67}$

Despite this early $i \bar{j} \bar{a} z \bar{a} t$, al-Dhahabī only began seriously and actively hearing hadith by himself at the age of 18 . The serious engagement with hadith studies began after he had met the historian and hadìth scholar 'Alam al-Dīn alQāsim al-Birzālī (d. 739/1338). ${ }^{68}$ According to al-Dhahabī, his friend and teacher al-Birzālī had awakened his interest and passion in the field of hadīth (huwa lladhi habbaba ilayya talab al-hadith) with some motivating words by telling him that his handwriting resembled that of the hadith scholars. ${ }^{69}$ After this, al-Dhahabi's eagerness to collect narrations must have been very strong. AlDhahabī's mashyakha counts 1043 individuals. ${ }^{70}$

Al-Dhahabī was educated by Kamāl al-Dīn b. al-Zamlakānī (d. 742/1342) in Shāfiì fiqh, who has been mentioned above. Al-Dhahabī also studied with Jamāl al-Dīn Yūsuf al-Mizzì (d. 742/1340) and held close relations with the younger historian Ibn Kathìr. They can all be described as traditionalists. Moreover, almost all of al-Dhahabī's teachers, himself included, had educational ties to students of Ibn al-Ṣalāḥ. This is true for al-Mizzī, al-Zamlakānī, and al-Birzālī, who studied with al-Tāj al-Fazārī, ${ }^{71}$ heard from al-Shihāb al-Khuwayy, from al-Majd b. al-Mihtār (d. 686/1387), ${ }^{72}$ al-Jamāl al-Sharīshī (d. 685/1386), ${ }^{73}$ and from al-Fakhr al-Baclabakkī l-Ḥanbalī (d. 688/1289). ${ }^{74}$

Hence, it is justified to reach the conclusion that al-Dhahabi not only maintained close relations to the network of students of Ibn al-Ṣalāh. As a traditionalist himself, he is most likely to also have supported the intellectual orientation of Ibn al-Ṣalāḥ in terms of both a more hadìth-based approach to jurisprudence

66 Ibn Hajar, Durar iii, 336.

67 For the biography of Ibn al-'Aț̣āar, see also Ibn Ḥajar, Durar iii, 5-7.

68 Al-Ḥāfiẓ, Dūr al-Hadīth 15, 205; al-Dhahabī, Tārīkh ixv, 773. Al-Birzālī had studied with alTāj al-Fazārī (d. 69o/1291) (one of the close students of Ibn al-Ṣalāh and a teacher in the Dār al-Ḥadīth al-Nūriyya), heard from al-Shihāb al-Khuwayy (d. 693/1294) (also a close student), and was appointed as shaykh in the Dār al-Hadīth al-Nafissiyya in around 717/1317 and al-Nūriyya in around 724/1324.

69 Al-Shaykh, al-Hāfiz 112.

70 Al-Dhahabī, Mújam.

71 See al-Dhahabī, Tārīkh xv, 66o-1.

72 See Ibid., 563 .

73 Ibid. 55 o.

74 Ibid.6o9. 
and the rejection of logic and Greek philosophy. This conclusion is supported by at least two facts. First, al-Dhahabì informs his readers in the entry on Ibn al-Ṣalāh in his Siyar a lām al-nubalä’ about himself having studied and heard the Muqaddima from many of the former's students. There, al-Dhahabi states that 21 individuals ${ }^{75}$ had heard the Muqaddima from Ibn al-Ṣalāh and that all of them, except for one, had also given al-Dhahabī permission to narrate it. ${ }^{76}$ Second, al-Dhahabi addressed the question of the proper understanding of the Divine attributes himself in at least three treatises, expressing in them the traditionalist point of view of accepting the expressions without any allegorical interpretation. Those treatises are al-Dhahabìs short collection of prophetic hadīth on the al-nuzūl (God's descent into the undermost heaven), his collection on God's attributes (ahâadith aș-șifät), a 40-hadìth collection, also on God's attributes (al-Arba'ünfì sifät rabb al-'ālamīn), and his controversial and much discussed book on the "Being above of God" (al-'Ulūw li-l-alı̀ al-ghaffär), in which he gathered Quranic verses, Prophetic traditions, and sayings of the Prophet's companions as well as later scholars. ${ }^{77}$ In those books and collections, he refuses allegorical interpretations of anthropomorphic expressions, claiming that the acceptance of the wording without questioning the how is the way of the salaf.

Eventually, al-Dhahabī's intellectual closeness to Ibn al-Ṣalāh and the social closeness to the latter's students' circle is also supported by the fact that alDhahabì authored a treatise on the 'ulüm al-ḥadìth, his al-Mūqiza fì 'ilm muștalah al-hadith. ${ }^{78}$ While Egyptian authors of the late Mamluk period, such as al-Suyūțī, saw al-Dhahabỉs Mūqiza as an abridgment of the Muqaddima of Ibn al-Ṣalāḥ, ${ }^{79}$ there seemed to be some debate about this among present-day Arab scholars. The editor of the Mūqiza, 'Abd al-Fattāh Abū Ghudda, believes that

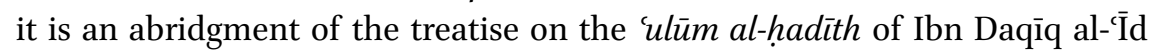
entitled al-Iqtirāh fí bayān al-iștiläh, which is supposed to be an abridgment of

75 Those are Tāj al-Dīn and his brother, al-Fakhr al-Karjī, al-Zayn al-Fāriqī, al-Majd b. alMihtār, al-Majd b. al-Ẓahīr, Zahīr al-Dīn Maḥmūd al-Zanjānī, Ibn 'Arabshāh, al-Fakhr al-Bađ'ī, al-Sharīshī, al-Jazā’inī, Muhammad b. al-Kharqī, Muḥammad b. Abī l-Dhikr, Ibn al-Khuwayy, Aḥmad al-Shahrazūrī, al-Șard al-Urmawī, al-Șadr khațīb Baclabakka, al-'Imād Muḥammad b. al-Ṣāìgh, al-Kamāl b. al-'Ațțār, Abū l-Yumn b. 'Asākir, and 'Uthmān b. 'Umar al-Mu'addal. See al-Dhahabī, Siyar, 266o.

76 See Ibid.

77 See Ma'rūf, al-Dhahabī, 145-6, 148-9.

78 See the modern editions of it by 'Abd al-Fattāh Abū Ghudda (Maktaba al-Mațbūāt alIslāmiyya in Aleppo) and 'Amr 'Abd al-Mun'im Salīm (Dār Uhud). 
the Muqaddima of Ibn al-Ṣalāḥ. ${ }^{80}$ Either way, al-Dhahabī's treatise is obviously strongly influenced by Ibn al-Ṣalāḥ's Muqaddima in terms of structure, content, and scholarly opinions. ${ }^{81}$

Another important fact needs to be mentioned here. Despite the fact that alDhahabī had already been appointed in the Dār al-Hadìth in the Turbat Umm al-Ṣaliḥ, in the Dār al-Ḥadīth al-Ẓāhiriyya, in the Dār al-Ḥadīth al-Nafìsiyya, in the Dār al-Ḥadīth al-Tankiziyya, in the Dār al-Hadīth al-Fāḍiliyya, and in the Dār al-Hadìth al-'Urwiyya, ${ }^{82}$ he seemed to have a strong personal wish to also teach in the Dār al-Hadìth al-Ashrafiyya. According to Ibn Qāḍī Shuhba, al-Dhahabī pursued an appointment at the Dār al-Hadìth al-Ashrafiyya after the death of al-Mizzì. However, due to his writings on the Divine attributes and the rejection of any allegorical interpretation, it was clear that al-Dhahabī was not an adherent of the Asharī school of theology, given that its most characteristic position is the allegorical interpretation of the Quranic verses on the attributes of God. Therefore, he was denied to be al-Mizzìs successor, and al-Taqī al-Subkī was appointed instead. ${ }^{83}$

This means that al-Dhahabì had been affected by the (intellectual) change that was going on in the teaching institutions in Damascus. In fact, his teacher al-Mizzī also ran into the same kind of trouble shortly before he was appointed in 718/1318. Some local Damascenes seemed to have objections against accepting his mashyakha there, as Ibn Kathīr and al-Subkī inform their readers. ${ }^{84}$ According to al-Subkī, the main concern that was brought forward against the appointment of al-Mizzī was that al-Mizzī was not an adherent of the Ash'arī school of theology. Allegedly, it was written in the endowment deed that the teacher (shaykh) of this Dār is supposed to be an adherent of the Ash'arī school. And although al-Mizzì had made a written statement that he followed this school, the Damascene scholars did not believe him and demanded his dismissal. ${ }^{85}$ Certainly, the events in 705/1306, in which al-Mizzì was imprisoned, had a role in the negative image that Damascene scholars had about al-Mizzī. In the month Rajab of that year, al-Mizzì gave a lecture on the chapter "The creation of the servants' deeds" (khalq af'āl al-ibād) of the Șahịh al-Bukhārī

\footnotetext{
8o Al-Dhahabī, Mūqiza $5^{-6 .}$

81 See, for a comparison between the three treatises of Ibn al-Ṣalāh, Ibn Daqīq al-Īd, and al-Dhahabī, Gharaibeh, Intertextuality.

82 See Márūf, al-Dhahabī 106-10.

83 See Ibn Qāḍī Shuhba, Tabaqāt iii, 74.

84 See Ibn Kathīr, Bidāya xviii, 181; al-Subkī, Tabaqāt x, 397-8. Both scholars, though, are very vague when it comes to the question of who exactly opposed the appointment of al-Mizzi. Al-Subkī refers to them as ahl dimashq, while Ibn Kathīr states limā fì nufüs ba'd al-nās.

85 Al-Subkī, Țabaqāt x, 397-8.
} 
in which al-Bukhārī reacted to the creed of the Jahmiyya. During this lesson, doubts about al-Mizzī's beliefs arose, and the Shāfīi chief judge Ibn Șarșā had him arrested for several days. ${ }^{86}$

For the purpose of this paper, it is not so important to determine what was behind those claims and what kind of creed al-Mizzī followed. Rather, it is important to note that among the list of the writings of Ibn al-Ṣalāh, the endowment deed of the Dār al-Ḥadìth al-Ashrafiyya-apparently no longer extant—is mentioned. ${ }^{87}$ Therefore, it seems very crucial to determine what kind of intellectual (or theological) orientation Ibn al-Ṣalāh had. Or rather, from the perspective of the scholars of this time, it is crucial to understand how Ibn al-Ṣalāh is depicted in the biographical dictionaries.

\subsection{Ibn Kathīr}

The case of Ibn Kathīr is quite similar to that of al-Dhahabī. Ibn Kathīr, whose full name is 'Imād al-Dīn Abū l-Fidā’ Ismāîl b. Kathīr, was born in 701/1301 in the village Majlad al-Qarya in the east of Damascus. He moved to the Syrian capital around 706/1306, shortly after the death of his father. ${ }^{88}$ In Damascus, Ibn Kathīr quickly entered the circles of the traditionalist Shāfi'is that al-Dhahabī also belonged to. During his education at the Bādirāiyya school where the Muqaddima of Ibn al-Ṣalāh was assumingly taught from 66o/1262 onward by students of Ibn al-Ṣalāḥ, Ibn Kathīr studied under al-Burhān Ibrāhīm al-Fazārī (d. 729/1329). ${ }^{89}$ Al-Burhān al-Fazārī was known for his traditionalist orientation, ${ }^{90}$ was the son of one of the closer students of Ibn al-Salāh, one of the transmitters of the Muqaddima, and led the prayer (imām) in the Rawāhiyya school. ${ }^{91}$ Besides the fact that al-Burhān introduced Ibn Kathīr to the traditionalist orientation, ${ }^{92}$ he might have also connected him to the circle of Ibn al-Ṣalāḥ̣'s students. After Ibn Kathīr began studying hadìth more seriously, he became a student of Jamāl al-Dīn al-Mizzì, who not only was one of his most

86 See Ibn Kathīr, Bidāya xviii, 54 .

87 See the introduction by the editors of Ibn al-Ṣalāh, Márifat 27. See also Ibn Kathīr, Bidāya xvii, 282, who mentioned that Ibn al-Ṣalāḥ authored the endowment deed (wa-huwa lladhī șannafa kitāba waqfiyhā).

88 Laoust, Ibn Katīir, 42-3.

89 Laoust, Ibn Katīir 43-4. Al-Burhān's full name is Ibrāhīm b. 'Abd al-Rahmān b. Ibrāhīm b. al-Farikāḥ al-Fazārī. He was born in 66o/1262 and received his education from his father and others. See, for his biography, Ibn Ḥajar, Durar i, 34-5.

$90 \quad$ Mirza, Ibn Kathïr 66n26.

91 See Ibn Hajar, Durar i, 34-5.

92 See Laoust, Ibn Katīir 44; Ohlander, Ibn Kathīr 15o. 
influential teachers but also became his father-in-law. ${ }^{93}$ Ibn Kathīr also held close ties to al-Dhahabī, who has been discussed above. Another Shāfīì scholar close to Ibn Kathīr was al-'Alam al-Qāsim al-Birzālī (d. 739/1338), a Shāfi'ì traditionalist who was known for his efforts in the fields of historiography and hadìth studies. ${ }^{94}$

From Ibn Kathīr's social contacts, one can already see a certain (imagined) closeness to Ibn al-Ṣalāh and (actual) closeness to the latter's students. His intellectual closeness is expressed in several aspects. First, Ibn Kathīr's Quran commentary, entitled Tafsìr al-Qur'ān al-Až̀m, was a traditionalist counterconcept to the commentary of the Shāfi'i rationalist al-Fakhr al-Rāzī, as Mirza recently pointed out convincingly. ${ }^{95}$ It, therefore, expresses Ibn Kathïr's rejection of logic and Greek philosophy, as Ibn al-Ṣalāḥ did as well. Second, Ibn Kathīr compiled an abridgment of the Muqaddima, entitled al-Bä ith al-hathïth

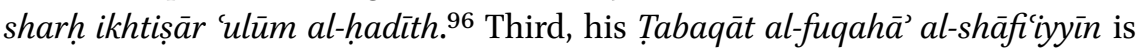
actually also an extension of the Tabaqāt work that Ibn al-Ṣalāh authored, and that al-Nawawī extended, as he expressed himself. ${ }^{97}$ Fourth, Ibn Kathīr was appointed at the Dār al-Hadith al-Ashrafiyya, the institution of teaching hadïth in which Ibn al-Ṣalāḥ authored his Muqaddima, at some point between 771/1370 (the death of the former teacher al-Tāj al-Subkī) and 774/1373 (Ibn Kathïr's death). ${ }^{98}$ Although it cannot be known with certainty, one can assume that Ibn Kathïr most likely authored his commentary on the Muqaddima as well during his teaching time at this institution as sort of a teaching manual. The fact that Ibn Kathīr follows Ibn al-Ṣalāḥ's outline and opinions in the commentary on the Muqaddima supports the conclusion of an intellectual closeness to Ibn al-Ṣalāh.

The analysis of the biographies of both al-Dhahabī and Ibn Kathīr reveal a clear traditionalist orientation. While this is not new, since previous studies

93 Ohlander, Ibn Kathīr 15 o.

94 See, for a comprehensive biography of al-Birzālī, Mirza, Ibn Kathìr 37-8.

95 See Mirza, Was Ibn Kathīr; Ibn Kathìr. The first cited article of Mirza summarizes the findings of his $\mathrm{PhD}$ thesis.

96 In some sources his mukhtașar is also referred to as Ikhtișār 'ulüm al-hadīth. There are two editions of the text, one edited as al-Bā ith and the other as Ikhtișār (see bibliography).

97 Ibn Kathīr, Țabaqāt ii, 783 .

98 Sources are not clear about his appointment. Al-Nu'aymī only lists the teachers in chronological order until Taqī al-Dīn al-Subkī, who died in 756. After that he names Ibn Kathīr and al-Tāj al-Subkī as successors with a remark that the order is not known. See al-Nu'aymī, Dāris i, 15-27. Listed after are: al-Tāqī al-Subkī, his son al-Tāj, then the Cairene scholar alSirāj al-Bulqīnī, who died in $80_{5}$ and was appointed as judge over Damascus during these years, and then Ibn Kathīr. See al-Ḥāfiz, Dūr al-Hadīth 6o. 
have suggested the same, ${ }^{99}$ the present paper adds to this at least three important aspects. Both scholars had close relations to the network of Ibn al-Ṣalāh's students, they both commented on the Muqaddima of Ibn al-Ṣalāh, which, hence, can be described as a central text for both scholars, and third, the Dār al-Hadìth al-Ashrafiyya played a crucial role in the lives of both scholars. With these findings, their description of Ibn al-Ṣaāḥ's life in their biographical dictionaries shall be compared.

\section{The Entries on Ibn al-Ṣalāh}

The following table shows three entries of al-Dhahabīs Siyar a'ām al-nubalä, Tārīkh al-islām, and Tadhkirat al-huffäz that contain Ibn al-Ṣalāh's biography. In the last column, the entry of Ibn al-Ṣalāḥ in Ibn Kathīr's Ṭabbaqāt is demonstrated. Only the parts in Arabic are crucial for the argument of the paper. The other information is only summarized. Each column roughly represents a paragraph, so that one can get an idea of what the structure and the content of the entire entry look like.

The entries of Ibn Kathīr and al-Dahabī in their writings follow a similar outline and make almost the same statement. First, they introduce Ibn al-Ṣalāh by citing his name and his birthdate. While Ibn Kathīr goes over the early education of Ibn al-Ṣalāh, al-Dhahabī inserts an anecdote that should emphasize Ibn al-Ṣalāḥ's extraordinary scholarly capacity that already appeared during his adolescence (see Tārīkh al-islām, Tadhkirat al-huffäz). After both scholars outline Ibn al-Ṣalāḥ's early and late education, both introduce descriptions about Ibn al-Ṣalāḥ's intellectual orientation, which can be perceived - from the perspective of the present study — as the main message and knowledge of the entries. Here, both scholars support their own worldview and use Ibn al-Ṣalāh as an authority. Ibn Kathīr states, "He was on the path of the Salaf with regard to the creed and hated the path of [Greek] philosophy and logic. Moreover he warned [his surroundings] against it [s danger] and prevented it from being taught while he was supported by the rulers in this. He had strong fatwās and righteous opinions." 100

Al-Dhahabī basically gives the same impression. In his Siyar, he states that Ibn al-Ṣalāh "was of solid creed on the path of the salaf and of right religious orientation (nihla). He prevented from entering into what lets the feet slip (mazallät al-aqdām)," which is a reference to the study of philosophy and logic.

99 See, for example Mirza, Ibn Kathir; Bori, Ibn Taymiyya; and Fancy, Science.

100 Ibn Kathīr, Țabaqāt ii, $782-3$. 
Al-Dhahabī adds that "he [Ibn al-Ṣalāḥ] believed in God and in His Names and Attributes." In the Tārīkh, al-Dhahabī is more explicit: "He was of right creed on the path of the salaf. He prevented from any allegorical interpretations [of the Quran, in particular the Divine attributes] and believed in what was narrated from God and his Prophet the way it was meant." And in his Tadhkirat al-huffäz, al-Dhahabī adds a few details while stating that "he was a Salafı of good creed (husn al-itiqād), who distanced himself from the allegorical interpretations of the mutakllimūn."

A comparison between Ibn Kathīr and al-Dhahabī reveals a great similarity between both characterizations, which fit the intellectual orientations of both scholars. Al-Dhahabī, however, included more information and was more specific about what exactly the "Salafì creed" looked like from his perspective, i.e., the belief in the names and attributes of God without any allegorical interpretations (of the mutakallimūn) and the rejection of logic and Greek philosophy.

In addition and in support of his explanations, al-Dhahabì included in his Siyar and the Tārīkh Ibn al-Ṣalāḥ's fatwā on the ban of philosophy. Although al-Dhahabī did not cite the entire fatwa $\bar{a}$, the quoted passages largely match the words of Ibn al-Ṣalāh in the latter's collection of fatwās. ${ }^{101}$ The first passage he cited speaks about philosophy as the root of all disbelief and evil. For Ibn alȘalăh, the engagement in philosophy blinded the sight for the Divine sharīa, which is supported by clear evidence. The part that al-Dhahabī left out speaks about the Prophet's miracles, indicating that those who study philosophy do not believe in the prophethood of Muhammad despite all the signs and miracles. In fact, in the opinion of Ibn al-Ṣalāh, the miracles of the Prophet were not restricted to his lifetime but were also visible in the miracles of the awliya $\bar{a}^{2}$ (karamāt al-awliya $\bar{a}^{3}$ ) and even every time a believer asks God for help through the intercession of the Prophet. ${ }^{102}$ Whether or not al-Dhahabī left this passage out because he disagreed with Ibn al-Ṣalāh is not easy to answer, since he did not seem to have addressed the question of intercession with the Prophet particularly. In general, he seemed to have approved the existence of the karamāt of $a w l i y \vec{a}$, as he also condemned exaggerations and deviations from what he defined as the path of the salaf. ${ }^{103}$ The next passage that al-Dhahabi cited from the fatwa concerned the ban of using logic, warning of its bad impact and emphasizing that the Divine sharîa was not in need of logic in any way. Ibn Kathīr did not include the fatwā in his entry on Ibn al-Ṣalāḥ.

\footnotetext{
101 For the entire fatwā, see Ibn al-Ṣalāh, Fatāwā i, 209-12.

102 See Ibn al-Ṣalāḥ, Fatāwā i, 210.

103 For an overview of passages in his historical writings that approve the existence of karamāt, see 'Abd al-Ḥaqq al-Makkī, Mawqif 93-109.
} 
TABLE 6.1 The entries on Ibn al-Ṣalāh

Siyar a lām al-nubalä $\bar{a}^{104}$

Name

Date of birth

Early education

Later education

Who learned from him

Anecdote about his scholarly acumen reported by Ibn Khallikān

Personal characteristics reported by 'Umar b. alHājib

Personal characteristics reported by al-Dhahabī:

$$
\text { كان ذا جلالة عجيبة ووقار وفصاحة وعلم نافع وكان متين }
$$

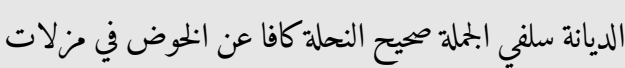

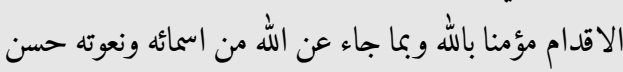

$$
\text { البزة وافر الحرمة معظما عند السلطان }
$$

[...] mentioning of his samāe contacts
Tärīkh al-islāmm ${ }^{105}$

Name

Date of birth

Anecdote of Ibn Khallikān (short version)

Early education and from whom he heard

Teaching positions

\section{Personal characteristics}

Anecdote about his scholarly acumen reported by Ibn Khallikān

Personal characteristics reported by Ibn al-Hājib

Personal characteristics reported by al-Dhahabī:

$$
\begin{aligned}
& \text { قلت: كان حسن الاعتقاد على مذهب السلف يرى الكف } \\
& \text { عن التأويل ويؤمن بما جاء عن الله ورسوله على مرادهما ولا } \\
& \text { يخوض ولا يتعمق } \\
& \text { من فتاويه أنه سئل عمن يشتغل بالمنطق والفلسفة فأجاب: }
\end{aligned}
$$

$$
\begin{aligned}
& \text { الفلسلة أس السفه والانحلال ومادة الحيرة والضلال ومثار } \\
& \text { الزيغ والزندقة ومن تفلسف عميت بصيرته عن محاسن الشريعة } \\
& \text { المؤيدة بالبراهين ومن تلبس بها قارنه الخذلان والحرمان } \\
& \text { واستحوذ عليه الشيطان وأظلم قلبه عن نبوة محد }
\end{aligned}
$$

104 Al-Dhahabī, Siyar 2659-6o.

105 Ibid., Tärīkh xiv, 455-7. 
Tadhkirat al-ḥuffā $z^{106}$

Ibn Kathīr, Ṭabaqāt al-Shāfíiyya ${ }^{107}$

Name

Date of birth

Anecdote of Ibn Khallikān (short version)

Early education and from whom he heard

Teaching positions

\section{Name}

Early education and from whom he heard

Teaching positions

scholarly characteristics

$$
\begin{aligned}
& \text { على طريقة السلف في الاعتقاد يكره طرائق الفلسفة والمنطق } \\
& \text { ويعظ منها ولا يمكّن من قراءتها بالبلد والملوك تطيعه في ذلك الك } \\
& \text { وله فتاوى سديدة وآراء رشيدة }
\end{aligned}
$$

\section{Mentioning of his writings}

Anecdote about his scholarly acumen reported Ibn al-Ṣalāḥ’s teachers by Ibn Khallikān

Personal characteristics reported by Abū Ḥafṣ Ibn List of who studied with him fiqh (tafaqqaha al-Hājib 'alayh)

Personal characteristics reported by al-Dhahabī: $\quad$ Date of his death and details on his funeral 
TABLE 6.1 The entries on Ibn al-Ṣalāh (cont.)

$$
\begin{aligned}
& \text { واستعمال الاصطلاحات المنطقية في مباحث الأحكام } \\
& \text { الشريعة من المنكرات المستبشعة والرقاعات المستحدثة وليس }
\end{aligned}
$$

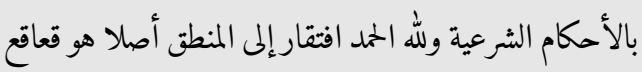

$$
\begin{aligned}
& \text { قد أغنى الله عنها كل صحيح الذهن فالواجب على السلطان }
\end{aligned}
$$

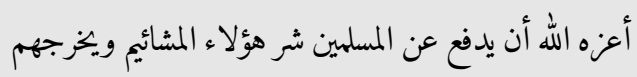

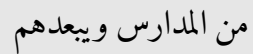

Mentioning of Ibn al-Ṣalāḥ̣'s fatwā against the study of philosophy:

من فتاويه أنه سئل عمن يشتغل بالمنطق والفلسفة لأجاب:

الفلسفة أس السفه والانحلال ومادة الحيرة والضلال ومثار الزيغ والزندقة ومن تفلسف عميت بصيرته عن محاسن الشريعة المؤيدة بالبراهين ومن تلبس بها قارنه الخذلان والحرمان واستحوذ عليه الشيطان وأظلم قلبه عن نبوة محمد

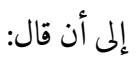

$$
\text { واستعمال الاصطلاحات المنطقية في مباحث الأحكام }
$$
الشريعة من المنكرات المستبشعة والرقاعات المستحدثة وليس بالأحكام الشرعية ولله الحمد افتقار إلى المنطق أصلا هو قعاقع قد أغنى الله عنها كل صحيح الذهن فالواجب على السلطان أعزه الله أن يدفع عن المسلمين شر هؤلاء المشائيم ويخرجهم

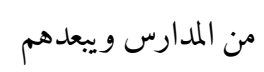

Mentioning of his popularity among the people and the Sultan 
TABLE 6.1 The entries on Ibn al-Ṣalāh (cont.)

Siyar a'lām al-nubalä̀

Date of his death and details on his funeral

A list of who heard the Ulüm al-hadìth from Ibn al-Ṣalāh with a reference that all of them have given al-Dhahabì an ijāza, except for one individual

\section{Tārīkh al-islām}

List of who studied with him fiqh (tafaqqaha 'alayh)

List of who narrated from him

Date of his death and details on his funeral 
List of who studied with him figh (tafaqqaha 'alayh)

List of who narrated from him

\section{Date of his death and details on his funeral}

List of individuals who died in the same year

Mention of a hadīth that al-Dhahabī narrates

from Ibn al-Ṣalāh through one of his students:

$$
\begin{aligned}
& \text { أخبرنا أبو العباس أحمد بن إبراهيم الفزاري المقرئ الخطيب } \\
& \text { المحدث النحوي } \\
& \text { ثنا أبو عمرو عثمان بن عبد الرحمن الحافظ } \\
& \text { أخبرتنا أم المؤيد زينب بنت أبي القاسم الشعرية وسمعت من } \\
& \text { زينب الكندية وابن أبي عصرون عنه } \\
& \text { أن إسماعيل ابن أبي القاسم أخبرها } \\
& \text { أنا عبد الغافربن محمد } \\
& \text { ثنا بشر بن أحمد } \\
& \text { ثنا داود بن الحسين } \\
& \text { ثنا يميى بن يميى }
\end{aligned}
$$


TABLE 6.1 The entries on Ibn al-Ṣalāḥ (cont.) 


$$
\begin{aligned}
& \text { أنا عبد الله بن محد بن أبي فروة } \\
& \text { يزيد بن خصيفة } \\
& \text { عن بسر.ن سعيد } \\
& \text { عن أبي هريزة قال } \\
& \text { قال رسول الله صلى الله عليه وآله وسلم أيما امرأة أصابت بخورا } \\
& \text { فلا تشهد معنا العشاء الآخرة } \\
& \text { عن زينب الثقفية بدل أبي هريرة }
\end{aligned}
$$$$
\text { وقد أخرجه مسلم بإسناد آخر عن بكير بن الأشج عن بسر فقال }
$$

Remark that this hadith indicates the prohibition for women even old ones to enter the mosques wearing perfume, citing two other hadith on this topic 
Another difference between Ibn Kathīr and al-Dhahabī is that the latter also includes in his Siyar a list of individuals who had narrated the Muqaddima from Ibn al-Ṣalāh. Besides the demonstration of the accuracy with which alDhahabì seemed to have put together this list, he also used this occasion to inform his reader that he received from all of those individuals- except onepermission to narrate the Muqqadima as well, thus highlighting the connection he had with Ibn al-Ṣalāh. This connection is also supported by the fact that alDhahabī cited in the Tadhkirat al-huffäz a hadith that he narrated with a full chain of transmission (isnād), in which Ibn al-Ṣalāh is also mentioned (with one intermediary between al-Dhahabī and Ibn al-Ṣalāḥ).

Despite these differences between Ibn Kathīr and al-Dhahabī, the picture that both scholars drew of Ibn al-Ṣalāḥ is the same. For them, Ibn al-Ṣalāh was a traditionalist scholar, as is proven by the remarks on his creed and the condemnation of philosophy and logic. In addition, both scholars sort of feel loyal to Ibn al-Ṣalāh due to their own intellectual orientation and their social closeness to the circle of Ibn al-Ṣalāh's students. Against the backdrop of the struggle between traditionalists and rationalists about teaching institutions in general and those that were dominated by Ibn al-Ṣalāḥ and his students (i.e., the Dār alḤadīth al-Ashrafiyya, the Dār al-Ḥadīth al-Nūriyya, and the Rawāḥiyya school), it can also be argued that the outline of biographies is meant to support the claims of traditionalists over these institutions. The argument that both scholars put forward seems to have run as follows: If the scholar who dominated these institutions in the first place was a traditionalist, traditionalists rather than rationalists should continue to teach there. Al-Dhahabi was obviously also trying to justify the appointment of his teacher al-Mizzī in the Dār al-Hadìth al-Ashrafiyya, in addition to his own ambitions to take over its mashyakha. Ibn Kathīr, who was appointed in the Dār al-Ḥadīth al-Ashrafiyya after two rationalists had already been appointed there in between—al-Taqī and al-Tāj al-Subkī - apparently attempted to reinstate the traditionalist image the Dār al-Hadìth al-Ashrafiyya used to have before.

In comparison to al-Dhahabī and Ibn Kathīr, al-Tāj al-Subkī shows a significant difference, not only with regard to the entry of Ibn al-Ṣalāh that he included in his Tabaqāt al-Shäfíyya but also with regard to his own biography and intellectual orientation.

Tāj al-Dīn 'Abd al-Wahhāb b. 'Alī al-Subkī was born in Cairo in 727/1327 or $728 / 1328$ into a family of scholars. His father, Taqī al-Dīn 'Alī, who was born in 
Subk, was a great Shāfi'i hadith scholar and jurist himself, and took over the early education of Tāj al-Dīn. ${ }^{108}$ In 739/1339, at the age of eleven, al-Tāj moved with his father to Damascus, where he continued his education, mostly with the local scholars. ${ }^{109}$ Although, as Berkey suggests, his education seems "typical of those of the leading ulama of the Mamluk period,"110 the information provided by Ibn Hajar about al-Täj's teachers, the works he read, the disciplines he specialized in, and the works he authored suggest that al-Tāj had a rather rational orientation compared to his traditionalist Shāfíi colleagues in Damascus. It is true that he studied with al-Mizzī and held close relations to al-Dhahabī; ${ }^{111}$ however, al-Subkī also criticized his teacher al-Dhahabī for his bias against Ash'arī-Shāfīi scholars as well as Sufis. ${ }^{12}$ Makdisi even goes as far as to describe the Tabaqāt of Tāj al-Dīn al-Subkī as work that, through the use of narrative strategies, shapes the historical image of the Shāfici school as rationalist oriented with tendencies toward Ash'arīsm. Following his predecessor Ibn 'Asākir, al-Subkī defended Ash'arī rationalism against the anthropomorphist Hanbalīs and traditionalist Shāfi îs of his time. ${ }^{113}$ Those also include, as was described above, his teacher al-Dhahabī and his colleague Ibn Kathīr. ${ }^{114}$ This impression goes together with the works Tāj al-Dīn al-Subkī read and wrote. Among those that Ibn Ḥajar lists are the Minhāj of al-Bayḍāwī and the Mukhtașar of Ibn alHaajib, both works on jurisprudence and legal theory. In addition, al-Tāj al-Subkī decided to write a larger work on legal theory (ușül al-figh) instead of, as his colleagues did, a work on the principles of hadìth studies ('ulüm al-ḥadìth).115

This is crucial information - and not only to identify the intellectual orientation of al-Subkī in comparison to Ibn Kathīr and al-Dhahabī. Since al-Subkī also took over the teaching in the Dār al-Hadìth al-Ashrafiyya after the death of his father in $756 / 1355$, it is important to notice that he did not compile a commentary on the Muqaddima of Ibn al-Ṣalāḥ as Ibn Kathīr did. Moreover, there is

108 See, for a short biography of both Taqī l-Dīn and Tāj al-Dīn al-Subkī, Berkey, al-Subkī 78. See also for slightly more information about the al-Subkī family, Schacht, al-Subkī ix, $743-5$.

109 See Ibn Hajar, Durar ii, 426.

110 Berkey, al-Subkī 8.

111 See Ibn Hajar, Durar ii, 425-8.

112 Al-Subkī, Țabqāt ii, 22-3; see also Irwin, Mamluk 161.

113 See Makdisi, Ash'arī esp. 57-79.

114 For the description of Ibn Kathīr as a traditionalist and his Ṭabaqāt as a means of shaping a traditionalist image of the Shāfīi school, see Mirza, Ibn Kathīr 10-22, 95-112, with examples from the Tabaqāt and the Bidāya of Ibn Kathīr.

115 See Ibn Ḥajar, Durar ii, 426. 
little indication that he had any contact with students of Ibn al-Ṣalāḥ at all.116 The only ones were al-Mizzī, Ibn Kathīr, and al-Dhahabī. Al-Subkī, however, criticized them for their traditionalist orientation, which is the characteristic feature that connects them to Ibn al-Ṣalāh. Moreover, Leder already stated that al-Taqi al-Subkī, the father of Tāj al-Dīn, did not attach much value to the public reading sessions of hadìth in the Dār al-Ḥadìth al-Ashrafiyya, so he did not continue this practice during his employment, which might also indicate that he no longer continued the tradition of teaching the Muqaddima of Ibn al-Ṣalāh..117 In continuation, al-Tāj al-Subkī might have followed his father's lead and done something different from his colleagues, so that the lack of any reference to any reading, studying, and teaching of and commenting on the Muqaddima can be interpreted as a strong indication that al-Subkī did not feel a deeper connection to the text in particular or the intellectual legacy of Ibn al-Ṣalāh in general.

Accordingly, the entry that al-Subkī included in his Țabaqāt al-shäfíiyya alkubrā about Ibn al-Ṣalāh differs significantly from the entries of al-Dhahabī and Ibn Kathīr.

Al-Subkī, Țabaqāt al-shāficiyya al-kubrā ${ }^{118}$

Name

List of places he achieved $s a m \bar{a}^{c}$ relations

Personal characteristics:

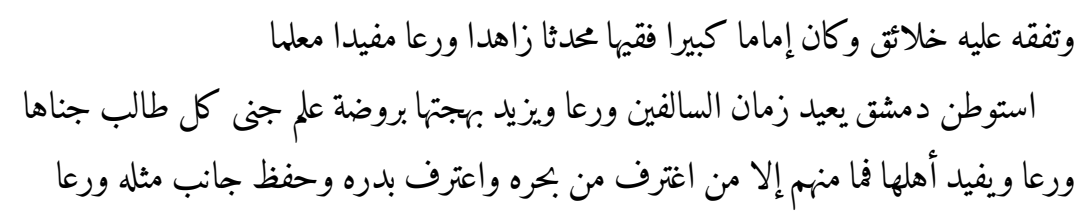

List of his teaching positions

Anecdote of Ibn Khallikān

Date of his death and details on his funeral

Al-Subkī, in total, shares much less information about Ibn al-Ṣalāh with his reader than his two traditionalist colleagues did. After he gives the full name and date of birth, he mentions that Ibn al-Ṣalāh had heard hadith in Mosul, Bagdad, Naysabur, Marw, and Damascus. In the next paragraph, al-Subkī lists

116 Ibn Ḥajar did not list any of the teachers of al-Subkī. See Ibn Hajar, Durar ii, 425-8.

117 Leder, Damaskus 248.

118 Al-Subkī, Țabaqāt viii, ${ }^{26} 6-36$. 
three individuals who narrated hadith from him. ${ }^{119}$ This is much less than the extensive list al-Dhahabi provided, for example, in the Tärīkh. There, he counted 18 individuals by name and added that others had heard from Ibn al-Ṣalāh as well (wa-ghayruhum). ${ }^{120}$ In al-Subkì's entry, Ibn al-Ṣalāḥ's influence and role in hadith do not appear that strong to the reader.

When al-Subkī speaks about Ibn al-Ṣalāh settling in Damascus, he uses the description salaf, as his colleagues did. However, instead of referring to a specific intellectual orientation or certain opinions regarding the creed and God's attributes, he uses it in a more general meaning of piety. He states that Ibn alȘalāh "brought back the piety of the time of the Salaf [or those who were before us] (yu'idu zaman al-sälifina war'an)." Al-Subkī, therefore, is aiming for a characterization of a general piety that Ibn al-Ṣalāh seemed to have been famous for. He, however, did not connect this piety with a certain intellectual orientation or any theological school. In fact, the use of the word sälifin instead of the word salaf, as al-Dhahabī and Ibn Kathīr did and which was more common among the traditionalists, could even have been meant in the sense of "those who were before us," as if al-Subkī meant that Ibn al-Ṣalāḥ attempted to remind society of the piety that it had lost and that previous people had.

The information al-Subkì further gives concerns the travels of Ibn al-Ṣalāh as well as his teaching positions. He also quotes Ibn Khallikān, stating that Ibn al-Ṣalāh was among the greatest in the disciplines of Quran exegesis, hadìth, and jurisprudence. In addition, al-Subkī supports the image of the pious Ibn al-Ṣalāh by quoting an anecdote that was narrated anonymously (wa-dhakar ghayruh). It was said that Ibn al-Ṣalāh once had said that he never did even a small sin (șaghìra) in his life. Al-Subkī closes this part of the entry with information on Ibn al-Ṣalāh's death date and his funeral.

The following part takes most of the space of the entry and contains Ibn al-Ṣalāḥ's legal opinions. On about eight pages from the total ten of the entry (in the modern edition), al-Subkī gives examples of Ibn al-Ṣalāh's fatwās. He touches upon topics such as the sale of a slave girl, the question of a man intending an optional prayer while he is sitting (not standing up during the prayer) (nadhara an yușallī $q \bar{a}$ cidan), inheritance matters, and some other topics, none of which has any connection with theology or creed.

As was expected, the entry in al-Subkīs Ṭabaqāt on Ibn al-Ṣalāh differs significantly. No references are found to Ibn al-Ṣalāḥ’s creed. Instead, al-Subkī refers to the general piety of Ibn al-Ṣalāh that he connects to the Sălifin. Other than

\footnotetext{
119 Those are al-Fakhr 'Umar b. Yahyā l-Karjī, Tāj al-Dīn al-Farikāḥ, and Aḥmad b. Hibat Allāh b.'Asākir. See al-Subkī, Ṭabaqāt viii, 326 .

120 Al-Dhahabī, Tārīkh xiv, 457.
} 
this, nothing gives the reader the impression that Ibn al-Ṣalāḥ was a traditionalist. By contrast, the long passage on Ibn al-Ṣalāḥ's fatwās, as well as the reduced list of individuals that heard hadith from him, give the impression of a jurist with little engagement in hadith. Against the backdrop of the struggle between rationalist and traditionalist Shāfi'is in Damascus in general and the competition about the Dār al-Hadìth al-Ashrafiyya, it is reasonable to conclude that al-Subkī aimed for a justification of his father's and his own appointment in the Dār. If the "founding father" Ibn al-Ṣalāh was rather a good jurist, as al-Taqī and al-Tāj al-Subkī appear, then the claims of traditionalists on predominance over the Dār is invalid.

\section{6}

\section{Conclusion}

The differences between the three scholars and their accounts on Ibn al-Ṣalāh are obvious and support the hypotheses of a bias-driven shape of historiography in general that Makdisi, Mirza, and Irwin note for the historical writings of al-Dhahabì, al-Subkī, Ibn Kathīr, and others as an expression of the opposite intellectual orientation to shape the image of a certain madhhab. ${ }^{121}$ As the analysis of the social networks of all three scholars demonstrates, the intellectual closeness to Ibn al-Ṣalāh, and hence the orientation toward traditionalism, as well as its distance from Ibn al-Ṣalāh, and the resulting orientation toward rationalism, go together with a social closeness to and distance from Ibn al-Ṣalāḥ and his students, respectively.

This appears to be a crucial finding against the backdrop of the ongoing struggle between rationalists and traditionalists in Damascus over teaching institutions during the 8th/14th century. This concerns especially those institutions in which Ibn al-Ṣalāḥ and his students were teaching the Muqaddima and that were for about 70 years dominated by them. In the 8th/14th century, these were given to rationalist Shāfiì scholars, who mostly migrated from Egypt to Damascus. To put the analysis of the biographical entries of Ibn al-Ṣalāh in this context highlights the personal interest each of the authors had while framing the biography of Ibn al-Ṣalāh. This is especially the case if one takes into consideration that these changes happened with the appointment of Taqi alDīn al-Subkī at the Dār al-Ḥadīth al-Ashrafiyya after the traditionalist Shāfíi al-Mizzī in 742. Since Ibn al-Ṣalāh was one of the first scholars who shaped the traditional image of these institutions and influenced their future through the

121 Makdisi, Ash`arī 59; Mirza, Ibn Kathīr 95-103; Irwin, Mamluk 161. 
network of his students, and since Ibn al-Ṣalāh also had written the endowment deed of the Dār al-Hadìth al-Ashrafiyya, it becomes self-evident that the depiction of Ibn al-Ṣalāh is crucial to all involved in the struggle over these institutions (i.e., al-Dhahabī, Tāj al-Dīn al-Subkī, and Ibn Kathīr). The different narrative strategies, the knowledge, and the overall framing of the entries can be seen as additional means by scholars of both camps to dominate in the struggle between traditionalism and rationalism and in the struggle over institutions. While al-Dhahabī and Ibn Kathīr wanted to defend al-Mizzì's appointment, as well as justify their own and reintroduce the traditional image of the school, Tāj al-Dīn al-Subkī was, obviously, justifying his father's appointment after alMizzī over al-Dhahabī.

\section{Bibliography}

\section{Primary Sources}

'Abd al-Ḥaqq al-Makkī, Mawqif a'immat al-haraka al-salafiyya min al-tașawwuf wa-lșüfiyya, n.e., Cairo Dār as-Salām ${ }^{3} 2001$.

Abū Shāma al-Maqdisī, Mukhtașar al-Mu'ammal fí l-radd ilā l-amr al-awwal, ed. Ṣ. Ahmad, Kuwait n.d.

Abū Shāma al-Maqdisī, Tarājim rijāl al-qarnayn al-sādis wa-l-sābi'al-ma' rūf bi-l-Dhayl 'alä l-Rawdatayn, ed. M. al-Kawtharī, Beirut ${ }^{2} 1974$.

al-Dhahabī, Tadhkirat al-huffāz, 4 vols., Beirut n.d.

al-Dhahabī, al-Müqizah fì IIm Muștalah al-Hadīth, ed. 'A. Abū Ghuddah, Aleppo 19845 .

al-Dhahabī, Mujam shuyūkh al-Dhahabī, ed. R.'A. al-Suyūfī, Beirut 199o.

al-Dhahabī, Tärïkhal-islām wa-wafayāt al-mashāhīr wa-l-alām, ed. B.'A. Márūf, 17 vols.,

Beirut 2003 .

al-Dhahabī, Siyar a 'āmm al-nubalā’, ed. Ḥ. 'Abd al-Mannān, Beirut 2004. al-Ḥāfiz, Dür al-hadīth al-sharîfa bi-Dimashq, Damascus 2010.

Ibn al-'Ațtāar, Tuhfat al-țālibin fi tarjamat al-imām Muhyūl-Dīn, in al-Nawawì, ed. A.'U.M.

b. Ḥasan Āl Salmān, Amman 2007.

Ibn 'Azzūz, Buyūtät al-hadīth bi-Dimashq, Damascus 2004.

Ibn Ḥajar al-'Asqalānī, al-Mujma al-mu'assis li-l-mújam al-mufahris, ed. Y.'A alMar'ashlī, 4 vols., Beirut 1992.

Ibn Ḥajar al-'Asqalānī, al-Durar al-kāmina fì a'yān al-mía al-thāmina, 4 vols., Beirut 1993 .

Ibn al-Imād, Shadharāt al-dhahab fi akhbār man dhahab, ed. 'A. al-Arnāūṭ and M. alArnāūț, 10 vols., Damascus and Beirut 1986.

Ibn Jamāca, Mashyakhat qāḍ̄ l-quḍāt, ed. M. 'Abd al-Qādir, 2 vols., Beirut 1988. 
Ibn Kathīr, al-Bā ith al-ḥathīth sharh ikhtiṣār ulūm al-ḥadīth, ed. A.M. Shākir, Beirut n.d. Ibn Kathīr, al-Bidāya wa-l-nihāya, ed. 'A. al-Turkī, 21 vols., Cairo 1997.

Ibn Kathīr, Țabaqāt al-shāficiyya, ed. 'Abd al-Ḥafizz Manșūr, 2 vols., Beirut 2004. Ibn Kathīr, Ikhtișār 'ulūm al-ḥadīth, ed. M.Y. al-Faḥl, Dār al-Maymān 1431/2010. Ibn Khallikān, Wafayāt al-a'yān wa-anbā’’ abnä’ al-zamān, ed. I. 'Abbās, 8 vols., Beirut 1978.

Ibn Qāḍī Shuhba, Tabaqāt al-shāfíiyya, ed. 'A. Khān, 5 vols., Hydarabad 1978.

Ibn al-Ṣalāḥ, Șiyānat Șaḥịn Muslim min al-ikhlāl wa-l-ghalaṭ wa-ḥimāyatuhu min alisqāt wa-l-saqaț, ed. M. 'Abd al-Qādir, Dār al-Gharb al-Islāmī 1984.

Ibn al-Ṣalāh, Adab al-muftīwa-l-mustaftī, ed. M. 'Abd al-Qādir, 'Ālam al-Kutub 1986.

Ibn al-Ṣalāḥ, Fatāwā wa-masāil Ibn al-Ṣalāh fì l-tafsìr wa-l-ḥadìth wa-l-uṣūl wa-l-fiqh, wa-ma'ahū Adab al-muftì wa-l-mustaftī, ed. 'A.A. Qal'ajī, 2 vols., Beirut 1986.

Ibn al-Ṣalāḥ, Ma'rifat anwā' 'ilm al-ḥadīth, ed. 'A. al-Hamīm and M.Y. al-Faḥl, Beirut 2002.

Ibn al-Ṣalāḥ, An Introduction to the Science of the Hadīth [Kitāb Ma'rifat anwā' cilm alhadith], trans. E. Dickinson, Garnet Publishing 2006.

Ibn al-Ṣalāh, Sharh mushkil al-Wasīṭ, ed. 'A.K.A. Bilāl, 4 vols., Riyadh 1432/2011.

al-Nawawī, Y., al-İjāz fì sharh Sunan Abī Dāwūd al-Sïjistānī, ed. A. 'U.M. b. Hasan Āl Salmān, Amman 2007.

al-Nu'aymī, 'A., al-Dāris fı̀ tārīkh al-madāris, ed. I. Shams al-Dīn, 2 vols., Beirut 1990. al-Ṣafadī, al-Wāfí bi-l-wafayāt, ed. A. al-Arnā'ūṭ and T. Mușțafā, 29 vols., Beirut 2000. al-Sakhāwī, M., al-Manhal al-'adhib al-rawīf ṫtarjamat quṭb al-awlyā’ al-Nawawī, ed. A.F. al-Mazīdī, Beirut 1971.

al-Subkī, Ṭabaqāt al-shāfíiya al-kubrā, ed. M.M. al-Ṭanāḥī and 'A.M. al-Ḥulūw, 10 vols., Cairo 1964.

al-Suyūṭ̂̄, al-Minhāj al-sawīf fi tarjamat al-imām al-Nawawī, ed. A.S. Damaj, Beirut 1988. al-Suyūṭī, al-Baḥr alladhī zakhar fí sharh Alfiyyat al-athar, ed. A.A. al-Andūnūsī, 4 vols., Medina 1999.

\section{Secondary Sources}

al-Azem, T., Traditionalism against scholasticism. The debate over "curriculum" in Damascus between 1150-1350, MA thesis, University of Oxford 2007.

Berkey, J., al-Subkī and his women, in MSR 14 (2010), 1-17.

Bori, C., Ibn Taymiyya wa-Jamā'atu-hu. Authority, conflict and consensus in Ibn Taymiyya's circle, in Y. Rappoport and S. Ahmed (eds.), Ibn Taymiyya and his times, Oxford 2010, 23-52.

Bulliet, R., Quantitative approach to medieval Muslim biographical dictionaries, in JESHO 13/2 (1970), 195-211.

Bulliet, R., Conversion to Islam in the medieval period. An essay in quantitative history, Cambridge 1979 . 
Bulliet, R., Age structure of medieval Islamic education, in $S I 57$ (1983), 105-17.

Conermann, S. (ed.), Innovation oder Plagiat? Kompilationstechniken in der Vormoderne, Berlin 2015.

Fancy, N., Science and religion in MamlukEgypt:Ibn al-Nafis, pulmonary transit and bodily resurrection, London and New York 2013.

Franz, K., Kompilation in arabischen Chroniken: Die Überlieferung vom Aufstand der Zang zwischen Geschichtlichkeit und Intertextualität vom 9. bis ins 15. Jahrhundert, Berlin 2004.

Gharaibeh, M., Intertextuality between history and ḥadīt studies. The Mūqiẓa fī cilm muștalah al-ḥadīt in the center of ad-Dahabī's (d. 748/1348) work, in T. Miura and S. Conermann (eds.), Studies on the History and Culture of the Mamluk Sultanate (1250-1517), Göttingen 2021, 255-289.

Gharaibeh, M., Narrative strategies in biographical dictionaries. The ad-Durar alKāmina of Ibn Ḥağar al-'Asqalānī-A case study, in S. Conermann (ed.), Mamluk historiography revisited. Narratological perspectives, Göttingen 2018, 51-75.

Gharaibeh, M., The sociology of commentarial literature-An analysis of the commentary tradition of the Muqaddimat Ibn aș-Ṣalāh (d. 643/1245) from the perspective of the sociology of knowledge, Habilitation thesis, University of Bonn 2019.

al-Ghouz, A., Brokers of Islamic philosophy in Mamlūk Egypt: Shams al-Dīn Mahmūd b. 'Abd al-Raḥmān al-Ișfahānī (d. 1348) as a case study in the transmission of philosophical knowledge through commentary writing, in S. Conermann (ed.) History and society during the Mamluk period (1250-1517) (Studies of the Annemarie Schimmel Institute for Advanced Study II), Göttingen 2016, 149-72.

Halim, F.A., Legal authority in premodern Islam: Yahyā b. Sharaf al-Nawawì in the Shāfī̄ school of law, London 2015.

Hirschler, K., Medieval Arabic historiography, authors as actors, London 2006.

Hirschler, K., Studying Mamluk historiography: From source-criticism to the cultural turn, in S. Conermann (ed.), Ubi Sumus? Quo vademus? Mamluk studies—State of the art, Göttingen 2013, 159-86.

Humphreys, S.R., From Saladin to the Mongols: The Ayyubids of Damascus, 1193-126o, Albany 1977 .

Irwin, R., Mamluk history and historians, in R. Allen and D.S. Richard (eds.), Arabic literature in the post-classical period, Cambridge 2006, 159-70.

Keshk, K., The historian's Mu'âwiya: The depiction of Mu'äwiya in the early Islamic sources, Saarbrücken 2008.

Keshk, K., How to frame history, in Arabica 56 (2009), 381-99.

Lahn, S., and J. Christoph Meister, Einführung in die Erzähltextanalyse, Stuttgart 2008. Laoust, H., Ibn Kat̄īr Historien, in Arabica 2/1 (1955), 42-88.

Leder, S., Charismatic scripturalism: The Hanbalī Maqdisīs of Damascus, in Der Islam 74 (1997), 279-304. 
Leder, S., Damaskus: Entwicklung einer islamischen Metropole (12.-14. Jh.) und ihre Grundlagen, in T. Bauer and U. Stehli-Werbeck (eds.), Alltagsleben und materielle Kultur in der arabischen Sprache und Literatur. Festschrift für Heinz Grotzfeld zum 70. Geburtstag, Wiesbaden 2005, 233-50.

Makdisi, G., Ash'arī and the Ash'arites in Islamic religious history I, in $S I 17$ (1962), 378 o.

Malti-Douglas, F., Texts and tortures: The reign of al-Mu'tadid and the construction of historical meaning, in Arabica 46/3 (1999), 313-36.

Ma'rūf, B.'A., al-Dhahabì wa-manhajuhū fì kitābih Tārīkh al-islām, Cairo 1976.

Mauder, C., Gelehrte Krieger: Die Mamluken als Träger arabischsprachiger Bildung nach al-Safadi, al-Maqrizi und weiteren Quellen, Hildesheim 2012.

Mirza, Y., Ibn Kathīr (d. 774/1373): His intellectual circle, major works and Qurānic exegesis, PhD diss., Georgetown University 2012.

Mirza, Y., Was Ibn Kathīr the "spokesperson" for Ibn Taymiyya? Jonah as a prophet of obedience, in JQS 16/1 (2014), 1-19.

Mourad, S.A., and J.E. Lindsay, The intensification and reorientation of Sunni jihad ideology in the Crusader period: Ibn 'Asākir of Damascus (1105-1176) and his age, with an edition and translation of Ibn 'Asākir's The forty hadiths for inciting jihad, Leiden 2012.

Ohlander, E., Ibn Kathīr (ca. 1301-1373), in J.E. Lowry, D.J. Stewart and R. Allen (eds.), Essays in Arabic literary biography 1350-1850, Wiesbaden 2009, 147-59.

Opwis, F.M., The role of the biographer in constructing identity and doctrine: Al'Abbādī and his Kitāb Țabaqāt al-Fuqahā' al-Shāfíiyya, in JAIS 11 (2011), 1-35.

Petry, C.F., The civilian elite of Cairo in the later middle ages, Princeton 1981.

Romanov, M, al-Raqmiyyāt. Digital Islamic history (https://alraqmiyyat.github.io/).

Romanov, M., Computational reading of Arabic biographical collections with special reference to preaching in the Sunnī world (661-1300 CE), PhD diss., University of Michigan 2013.

Schacht, J., Al-Subkī, in $E I^{2}$, ix, 743-5.

al-Shaykh, al-Hāfiz al-Dhahabī: Mu'arrikh al-islām, nāqid al-muhaddithìn, Damascus 1994 . 